\title{
Seminal plasma proteins and the reaction of spermatozoa from intact boars and from boars without seminal vesicles to cooling
}

\author{
H. D. M. Moore, G. A. Hall and K. G. Hibbitt \\ Agricultural Research Council, Institute for Research on Animal Diseases, \\ Compton, Nr. Newbury, Berkshire, U.K.
}

\begin{abstract}
Summary. Spermatozoa from intact boars and from boars without seminal vesicles were resuspended in diluent and cooled at different rates to $0^{\circ} \mathrm{C}$. Glutamic oxaloacetic transaminase and lactate dehydrogenase activities were greater in the diluents which had contained spermatozoa from intact boars than in those which contained spermatozoa from animals without seminal vesicles. The incubation of seminal plasma from an intact boar with spermatozoa from a vesiculectomized animal before cooling also increased the enzyme activity in the diluent. The factors responsible for this effect were associated with the basic protein fractions of boar seminal plasma, in particular the proteins with haemagglutinating activity which may have been adsorbed onto the spermatozoa. Spermatozoa were exposed to colloidal $\mathrm{Fe}(\mathrm{OH})_{2}{ }^{+}$to determine by electron microscopy the charge on the surface of the plasma membrane of washed epididymal spermatozoa and ejaculated spermatozoa from intact and vesiculectomized boars. Epididymal spermatozoa bound the positively charged particles more readily than the ejaculated spermatozoa from the intact boars, due to the absence of membrane-bound protein.
\end{abstract}

\section{Introduction}

Epididymal spermatozoa from a variety of domestic and laboratory animals appear to be more resistant to cold shock than ejaculated spermatozoa (Lasley \& Bogart, 1944; Lasley \& Mayer, 1944; Morita \& Chang, 1970). The factors responsible for this effect may reside in the accessory secretions, in particular the fluid of the seminal vesicles (Bennett \& Dott, 1967; Fulka, Surcova \& Valenta, 1965; Morita \& Chang, 1970). Acrosomes of boar spermatozoa from whole ejaculates have been shown to be more susceptible to cold shock than those from sperm-rich fractions (Pursel, Johnson \& Rampacek, 1972), suggesting that seminal plasma could be detrimental. Furthermore, the irreversible loss of motility that boar spermatozoa undergo when cooled to temperatures below $10^{\circ} \mathrm{C}$ (Polge, 1956) may be associated with haemagglutinin, a basic protein of seminal vesicle origin (Roberts, Boursnell \& Brown, 1974).

Boar seminal plasma contains a high concentration of basic proteins secreted by the seminal vesicles (Boursnell, Johnson \& Zamora, 1962). Since basic proteins increase the permeability of membranes (Ryser \& Hancock, 1965; Drew \& McLaren, 1970; Hibbitt \& Benians, 1971), it is possible that vesicular basic proteins may similarly affect boar spermatozoa by rendering them susceptible to damage during cooling and freezing for long-term preservation. A preparation of semen free of vesicular secretion can be obtained from boars which have had their seminal vesicles removed (Davies, Hall, Hibbitt \& Moore, 1975). In the present study, spermatozoa from intact and vesiculectomized boars were cooled to assess how detrimental vesicular secretion is to the longterm preservation of semen. The activity of enzymes released from the cells was used as a measure of membrane integrity and the membrane surface charge of the spermatozoa was also investigated. 


\section{Materials and Methods}

\section{Vesiculectomy}

Five Large White boars were selected from the Institute's minimal disease herd. Surgery, as described by Davies et al. (1975), was performed at 4-8 months of age on 3 boars which were then allowed to recover before being trained for semen collection. Two intact boars of the same litter, and therefore of similar age and genetic background, were retained as controls.

\section{Semen collection and electron microscopy of spermatozoa}

Semen was collected by the gloved-hand technique (Hancock \& Hovell, 1959) through gauze into a pre-warmed vacuum flask at $30^{\circ} \mathrm{C}$. Collections were made from all boars at weekly intervals. To obtain seminal plasma samples, the spermatozoa were removed from the semen immediately after collection by centrifugation at $1000 \mathrm{~g}$ for $30 \mathrm{~min}$ at $25^{\circ} \mathrm{C}$. The seminal plasma was carefully removed from the sedimented spermatozoa, filtered and stored at $-20^{\circ} \mathrm{C}$. The vesiculectomized boars were monitored for regeneration of the seminal vesicles by measuring citrate (Moellering \& Gruber, 1966) and protein (Layne, 1957) concentrations in the seminal plasma. Epididymal spermatozoa were obtained from boars immediately after slaughter by flushing the cauda epididymidis with Tyrode's solution at $30^{\circ} \mathrm{C}$ and then allowing spermatozoa to flow from the severed ductus deferens into a vacuum flask.

The sperm concentration of the semen was determined after collection using a Neubauer double counting chamber. Duplicate dilutions were made for each sample with the mean of four counts used for calculating the concentration.

Ejaculated and epididymal spermatozoa were washed in Tyrode's solution by centrifugation at $700 \mathrm{~g}$ for $4 \mathrm{~min}$ and fixed in $2.5 \%(\mathrm{v} / \mathrm{v})$ glutaraldehyde in $150 \mathrm{~mm}$-sodium cacodylate buffer, $\mathrm{pH} 7 \cdot 4$, for $1 \mathrm{hr}$ at $25^{\circ} \mathrm{C}$ (Jones, 1973). The cells, washed in cacodylate buffer, were post-fixed in $1.0 \%$ phosphate-buffered osmium tetroxide solution, pH 7.4, for $1 \mathrm{hr}$ at $5^{\circ} \mathrm{C}$ then washed again in $0 \cdot 1 \mathrm{M}$-phosphate buffer, dehydrated through graded alcohols and embedded in araldite. Some samples of fixed spermatozoa were rinsed twice in distilled water by centrifugation and then incubated for $30 \mathrm{~min}$ in an undialysed suspension of colloidal $\mathrm{Fe}(\mathrm{OH})_{2}{ }^{+}$at $\mathrm{pH} 1.6$ (Gasic, Berwick \& Sorrento, 1968). The spermatozoa were washed twice in $12 \%$ acetic acid and once in distilled water before post-fixation and embedding as described above.

Ultrathin sections, cut with an ultramicrotome (Reichert OMU2) were stained with lead citrate alone, or uranyl acetate and lead citrate, and examined with an electron microscope (Philips EM 300 , accelerating voltage $80 \mathrm{kV}$ ). The electron micrographs were scored according to differences in membrane structure, and for the amount of positively charged colloidal particles binding to sections of spermatozoa which had been incubated with $\mathrm{Fe}(\mathrm{OH})_{2}{ }^{+}$.

\section{Separation of protein fractions}

Intact boar seminal plasma was separated by gel filtration and ion-exchange chromatography into a large molecular weight acidic protein fraction and a smaller molecular weight basic protein fraction (Moore \& Hibbitt, 1976). To obtain basic protein with high haemagglutinating activity, seminal plasma was dialysed overnight against $0.01 \mathrm{M}$-tris- $\mathrm{HCl}$ buffer at pH 8.0 (Boursnell \& Briggs, 1969). The precipitation that formed was separated from the supernatant by centrifugation and dissolved in a minimum volume of $0 \cdot 1 \mathrm{M}$-acetate buffer, $\mathrm{pH} 4 \cdot 0$, and then fractionated by gel filtration, as for seminal plasma, into an acidic protein fraction and a fraction containing haemagglutinating activity as measured by the agglutination of pig red blood cells (Boursnell, 1967). The two basic protein fractions, designated (i) and (ii) (ii with high haemagglutinating activity), and the acidic protein fraction were coneentrated by dialysis against carbowax followed by dialysis in IVT diluent (du Mesnil du Buisson \& Jondet, 1961) and the protein concentrations adjusted to the level found in seminal plasma. 


\section{Enzyme assays}

The activities of glutamic oxaloacetic transaminase (GOT: L-aspartate 2-oxo-glutarate aminotransferase, E.C. 2.6.11) and lactate dehydrogenase ( $\mathrm{LDH}$ : D-lactate NAD oxidoreductase, E.C. 1.1.1.28) were measured in the extracellular medium after the incubation of the spermatozoa. The assay systems carried out in quartz cuvettes (1 cm light-path) were as follows. (1) GOT (Sizer \&

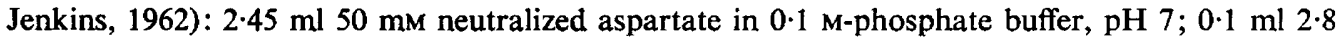
mM-NADH; $0.05 \mathrm{ml}(1100 \mathrm{U} / \mathrm{ml})$ malate dehydrogenase (E.C. 1.1.1.37); and $0.3 \mathrm{ml} \mathrm{sample.} \mathrm{The}$ reaction was initiated by the addition of $0.1 \mathrm{ml} \mathrm{0.2} \mathrm{M- \alpha -ketoglutarate.} \mathrm{(2)} \mathrm{LDH} \mathrm{(Kornberg,} \mathrm{1955):}$

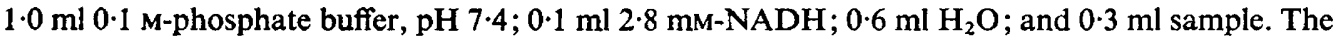
reaction was initiated by the addition of $1.0 \mathrm{ml} 10 \mathrm{~mm}$-pyruvate. For each sample duplicate assays were performed at $25^{\circ} \mathrm{C}$. The absorbance at $340 \mathrm{~nm}$ was determined automatically every $20 \mathrm{sec}$ with a spectrophotometer (Uvichem: Rank Ltd, London) and a chart recorder (Servoscribe 1S: Smith Industries, London). The change in absorbance $\mathrm{min}^{-1}$ was measured from the slope of the best straight line through the readings. Enzyme activities were calculated in units $(U) /$ spermatozoa $x$ $10^{9}$ where one unit of enzyme activity converts $1 \mu \mathrm{mol}$ substrate $\mathrm{min}^{-1}$ under the specified conditions.

\section{Experiment I}

Five semen samples from intact and five from vesiculectomized boars were centrifuged in 10 $\mathrm{ml}$ aliquots at $300 \mathrm{~g}$ for $10 \mathrm{~min}$ at room temperature. The supernatant seminal plasma was removed by aspiration and the spermatozoa gently resuspended with a Pasteur pipette in the equivalent volume of IVT diluent (du Mesnil du Buisson \& Jondet, 1961). The sperm concentration was $2-5 \times 10^{8}$ spermatozoa $\mathrm{ml}^{-1}$ for all samples. Duplicate $5 \mathrm{ml} \mathrm{samples} \mathrm{in} \mathrm{bijou} \mathrm{bottles} \mathrm{were} \mathrm{then} \mathrm{subjected} \mathrm{to} \mathrm{the}$ following incubation periods: (1) $25^{\circ} \mathrm{C}$ for $3 \mathrm{hr}$; (2) cooled to $5^{\circ} \mathrm{C}$ in a cooling machine (manufactured in the Institute's workshop) at a linear rate of $6^{\circ} \mathrm{C} \mathrm{hr}^{-1}$; (3) cooled rapidly with shaking to $5^{\circ} \mathrm{C}$ or $0^{\circ} \mathrm{C}$ by placing samples in a water bath at $5^{\circ} \mathrm{C}$ or in an ice bath for $3 \mathrm{hr}$. At the time of initial dilution and completion of the incubations, samples were centrifuged at $1000 \mathrm{~g}$ for $15 \mathrm{~min}$. The supernatant was removed gently by aspiration and filtered. A microscopic check was then made of the samples to ensure there was no contamination with spermatozoa before storage overnight at $-20^{\circ} \mathrm{C}$ prior to enzyme assays.

\section{Experiment II}

Five semen samples from vesiculectomized boars were centrifuged at $300 \mathrm{~g}$ for $10 \mathrm{~min}$ at room temperature. The supernatant was removed and the spermatozoa resuspended in the equivalent volume of seminal plasma at $25^{\circ} \mathrm{C}$ from an intact boar. Control samples of spermatozoa were resuspended in seminal plasma from a second vesiculectomized boar who had not ejaculated the original semen. Samples of resuspended spermatozoa were incubated in bijou bottles for $30 \mathrm{~min}$ at $25^{\circ} \mathrm{C}$ and then centrifuged at $300 \mathrm{~g}$ for $10 \mathrm{~min}$. The supernatants were removed from the samples and the spermatozoa resuspended in IVT diluent. These samples were then held at $25^{\circ} \mathrm{C}$ for $3 \mathrm{hr}$ or cooled to $0^{\circ} \mathrm{C}$ at a rate of $6^{\circ} \mathrm{C} \mathrm{hr}^{-1}$. After dilution, and at $5^{\circ} \mathrm{C}$ intervals, sperm samples which had been incubated in seminal plasma from both intact and vesiculectomized boars were removed, centrifuged, filtered and checked for sperm contamination before being stored at $-20^{\circ} \mathrm{C}$ overnight prior to enzyme assays.

\section{Experiment III}

The protein fractions used for this experiment were an acidic fraction, a basic fraction (i), and a fraction containing a high haemagglutinating activity (ii). These protein components were dialysed against IVT diluent and the protein levels adjusted so that they would be approximately equivalent to those found in the seminal plasma (Table 3).

Five samples of semen from vesiculectomized boars were collected and centrifuged in $2 \mathrm{ml}$ aliquots at $300 \mathrm{~g}$ for $10 \mathrm{~min}$. The supernatant was removed and the spermatozoa resuspended in 
the diluents containing the protein fractions, or in IVT diluent to a concentration of $2 \times 10^{8}$ spermatozoa $\mathrm{ml}^{-1}$. Duplicate samples for each protein fraction were then incubated for $4 \mathrm{hr}$ at $30^{\circ} \mathrm{C}$ or cooled from $30^{\circ} \mathrm{C}$ to $5^{\circ} \mathrm{C}$ over the same period. After the incubations the supernatants were removed as described above and stored at $-20^{\circ} \mathrm{C}$ for enzyme assays the following day.

\section{Results}

\section{Experiment I: enzyme released from spermatozoa of intact and vesiculectomized boars}

Cooling (slow or fast) resulted in a release into the diluent of significantly more enzyme activity from spermatozoa of intact boars compared with the spermatozoa of vesiculectomized boars (Table 1). There was a significant difference between the enzyme activities in samples of diluent incubated at, or cooled to, $5^{\circ} \mathrm{C}$ and $0^{\circ} \mathrm{C}$ and those incubated at $25^{\circ} \mathrm{C}$, or on initial dilution.

Table 1. Enzyme activity (means \pm S.D.; U/10 spermatozoa) in IVT diluent after various treatments of spermatozoa from intact and vesiculectomized boars

\begin{tabular}{lccccc}
\hline & Lactate dehydrogenase activity & & $\begin{array}{c}\text { Glutamic oxaloacetic transaminase } \\
\text { activity }\end{array}$ \\
\cline { 2 - 3 } \cline { 5 - 6 } \multicolumn{1}{c}{ Treatment } & Intact boars & $\begin{array}{c}\text { Vesiculectomized } \\
\text { boars }\end{array}$ & & Intact boars & $\begin{array}{c}\text { Vesiculectomized } \\
\text { boars }\end{array}$ \\
\hline Dilution at $25^{\circ} \mathrm{C}$ & $0.38 \pm 0.13$ & $0.26 \pm 0.12$ & & $0.05 \pm 0.21$ & $0.21 \pm 0.13$ \\
Kept at $25^{\circ} \mathrm{C}$ for $3 \mathrm{hr}$ & $0.60 \pm 0.19$ & $0.29 \pm 0.15$ & & $0.37 \pm 0.30$ & $0.45 \pm 0.29$ \\
Cooled to $5^{\circ} \mathrm{C}$ & $1.79 \pm 0.25$ & $0.37 \pm 0.15^{*}$ & & $2.51 \pm 0.70$ & $0.69 \pm 0.43^{*}$ \\
Cold shocked to $5^{\circ} \mathrm{C}$ & $1.71 \pm 0.26$ & $0.42 \pm 0.15^{*}$ & & $2.56 \pm 0.91$ & $0.82 \pm 0.50^{*}$ \\
Cold shocked to $0^{\circ} \mathrm{C}$ & $2.77 \pm 0.62$ & $0.84 \pm 0.41^{*}$ & & $3.60 \pm 0.81$ & $1.53 \pm 0.52^{*}$ \\
\hline
\end{tabular}

* Significantly different from corresponding values for intact boars, $P<0.001$.

Table 2. The activity of glutamic oxaloacetic transaminase (means \pm S.D.; $U / 10^{9}$ spermatozoa) in IVT diluent after incubation and cooling of vesiculectomized boar spermatozoa which had been preincubated in seminal plasma from intact and vesiculectomized boars

\begin{tabular}{|c|c|c|c|c|}
\hline \multirow[b]{2}{*}{ Treatment after dilution } & \multicolumn{2}{|c|}{$\begin{array}{c}\text { Preincubation in seminal plasma from } \\
\text { intact boars }\end{array}$} & \multicolumn{2}{|c|}{$\begin{array}{c}\text { Preincubation in seminal plasma from } \\
\text { vesiculectomized boars }\end{array}$} \\
\hline & Enzyme activity & $\%$ increase & Enzyme activity & $\%$ increase \\
\hline $25^{\circ} \mathrm{C}$ & $0.41 \pm 0.19$ & - & $0.46 \pm 0.04$ & - \\
\hline $25^{\circ} \mathrm{C}$ for $3 \mathrm{hr}$ & $0.44 \pm 0.07$ & 9 & $0.46 \pm 0.03$ & 4 \\
\hline $20^{\circ} \mathrm{C}$ & $0.53 \pm 0.06$ & 29 & $0.43 \pm 0.20$ & - \\
\hline $15^{\circ} \mathrm{C}$ & $0.56 \pm 0.19$ & 38 & $0.42 \pm 0.23$ & - \\
\hline $10^{\circ} \mathrm{C}$ & $0.84 \pm 0.28$ & 101 & $0.52 \pm 0.11^{*}$ & 15 \\
\hline $5^{\circ} \mathrm{C}$ & $1.03 \pm 0.25$ & 149 & $0.71 \pm 0.09^{*}$ & 56 \\
\hline $0^{\circ} \mathrm{C}$ & $1.32 \pm 0.23$ & 221 & $0.83 \pm 0.07$ & 84 \\
\hline Cold shocked to $5^{\circ} \mathrm{C}$ & $1.48 \pm 0.08$ & 272 & $1.01 \pm 0.05^{*}$ & 123 \\
\hline Cold shocked to $0^{\circ} \mathrm{C}$ & $1.73 \pm 0.09$ & 329 & $1 \cdot 17 \pm 0.12^{*}$ & 159 \\
\hline
\end{tabular}

* Significantly different from corresponding values for intact boars, $P<0.005$.

\section{Experiment II: enzyme released from spermatozoa after incubation in seminal plasma}

When spermatozoa from vesiculectomized boars were incubated in seminal plasma from an intact boar before being cooled, significantly more enzyme activity was measured in the diluent after cooling to $10^{\circ} \mathrm{C}$ or below, than in diluent in which spermatozoa had first been incubated in seminal plasma from a second vesiculectomized boar (Table 2). There was no difference in the enzyme activities of diluents when spermatozoa previously incubated in seminal plasma, from either an intact or vesiculectomized boar, were incubated at $25^{\circ} \mathrm{C}$ for $3 \mathrm{hr}$ or cooled to $15^{\circ} \mathrm{C}$. 


\section{Experiment III: enzyme released from spermatozoa after incubation in protein fractions}

Enzyme activities were significantly higher in the diluents containing basic proteins than in IVT diluent alone, after cooling to $5^{\circ} \mathrm{C}$ with vesiculectomized boar spermatozoa (Table 3). Incubation of spermatozoa with the acidic protein fraction in IVT did not cause a significant rise in the enzyme activities.

Table 3. The activity of glutamic oxaloacetic transaminase (means \pm S.D.; U/109 spermatozoa) in diluent after incubation of vesiculectomized boar spermatozoa with various protein fractions

\begin{tabular}{|c|c|c|c|}
\hline \multirow[b]{2}{*}{ Protein fraction } & \multirow{2}{*}{$\begin{array}{c}\text { Haemagglutinating } \\
\text { activity } \\
\text { (no. of wells } \\
\text { agglutinated) }\end{array}$} & \multicolumn{2}{|c|}{ Enzyme activity } \\
\hline & & $30^{\circ} \mathrm{C}$ for $4 \mathrm{hr}$ & $5^{\circ} \mathrm{C}$ for $4 \mathrm{hr}$ \\
\hline Acidic protein, $7 \mathrm{mg} \mathrm{ml}^{-1}$ & $0-2$ & $0.62 \pm 0.09$ & $0.94 \pm 0.19$ \\
\hline Basic protein (i), $23 \mathrm{mg} \mathrm{ml}^{-1}$ & $3-5$ & $0.79 \pm 0.12^{*}$ & $1.33 \pm 0.20^{*}$ \\
\hline Basic protein (ii), $10 \mathrm{mg} \mathrm{ml}^{-1}$ & $10-12$ & $1.25 \pm 0.17 \dagger$ & $1.58 \pm 0.15 t$ \\
\hline IVT diluent & 0 & $0.51 \pm 0.22$ & $0.68 \pm 0.14$ \\
\hline
\end{tabular}

$P<0.005 ; \dagger P<0.005$.

\section{Electron microscopy}

Ejaculated spermatozoa from intact and vesiculectomized boars scored equally well against epididymal spermatozoa with respect to membrane integrity. Protein was not detected binding to the membrane in any sample. In preparations stained with $\mathrm{Fe}(\mathrm{OH})_{2}{ }^{+}$, however, differences were observed in the binding of positively charged particles to the spermatozoa. Colloidal particles were attached to most of the plasma membrane of epididymal spermatozoa with binding also occurring along the tail. Ejaculated spermatozoa from vesiculectomized boars bound considerably fewer colloidal particles, although the binding appeared to be discriminate since some parts of the sperm head stained with particles attached along the plasma membrane and other parts were clear of colloid. Very few colloidal particles were seen attached to intact boar spermatozoa, and where binding had occurred the plasma membrane was usually broken.

\section{Discussion}

On cooling, significantly more enzyme activity was measured in diluents which contained intact boar spermatozoa than in those which contained spermatozoa from vesiculectomized boars. After dilution or incubation for $3 \mathrm{hr}$ at $25^{\circ} \mathrm{C}$, no difference was measured in the enzyme activities of diluents containing either type of spermatozoa, indicating that the enzyme release was associated with cooling and not the incubation time. The enzyme activity was due to release of enzymes from the spermatozoa, instead of the free cytoplasmic droplets, since the latter were removed in the supernatant after the initial centrifugation. Centripetal forces were $<1000 \mathrm{~g}$ to provide cell-free supernatants with the minimum of sperm damage since Pace \& Graham (1970) showed that forces up to $1500 \mathrm{~g}$ caused no significant release of enzyme above levels after dilution. The rate of cooling spermatozoa did not seem to affect the levels of enzyme activity in the diluents, as equal amounts of activity were measured after rapid or slow cooling, confirming the work of Polge (1956) who showed that boar spermatozoa were very susceptible to cold shock. The loss of cations and enzymes from spermatozoa has been studied extensively as a means of monitoring cold shock and deep freezing in most domestic and laboratory animals (Graham \& Pace, 1967; Pursel, Johnson \& Gerrits, 1968; Quinn \& White, 1966). In particular, GOT has been used to assess the quality of bovine spermatozoa for deep freezing (Pace \& Graham, 1970) and to study the effects of buffers and glycerol on boar spermatozoa (Crabo, Brown \& Graham, 1972; Bower, Crabo, Pace \& Graham, 1973). Both GOT and LDH are cytoplasmic enzymes located in the head and mid-piece, and release of these enzymes from the cell there- 
fore reflects the integrity of the plasma membrane rather than the fertilizing capacity of the spermatozoa.

Preincubation of the spermatozoa from vesiculectomized boars with intact boar seminal plasma significantly increased the enzyme activity in the diluent after cooling above the levels obtained by preincubation with seminal plasma from a second vesiculectomized boar. As most of the seminal plasma was removed from the spermatozoa before cooling in diluent, the factors responsible for this effect had probably become bound or associated with the spermatozoa, or caused changes to the spermatozoa which were only manifest on cooling. The amount of enzyme activity in the diluent after incubation was less in the second experiment, however, than in the first, indicating that the factors could be labile. The spermatozoa did not agglutinate when resuspended in seminal plasma of a normal or vesiculectomized boar. This, and the fact that the animals were litter mates, suggested that the effect was not an auto-antibody reaction causing breakdown of the cells. Incubation of boar spermatozoa with seminal plasma protein fractions demonstrated that the basic proteins were responsible for the release of the enzyme and that the haemagglutinating activity was associated with this effect. Although in most cases the enzyme release became obvious only after cooling, the fraction containing the most haemagglutinating activity released the sperm enzyme even when incubated at $30^{\circ} \mathrm{C}$.

Epididymal spermatozoa from a variety of animals adsorb protein from the seminal vesicles (Weil \& Finkler, 1958; Matousek, 1964) and basic proteins from boar seminal plasma have been shown to bind to the spermatozoa of intact and vesiculectomized boars (Moore \& Hibbitt, 1976). Initial electron microscopy of the various types of spermatozoa did not reveal any changes in sperm membrane or the binding of protein to the surface. However, exposure of the cells to positively charged colloidal $\mathrm{Fe}(\mathrm{OH})_{2}{ }^{+}$indicated that there were differences in surface charge of the sperm membrane which depended on the origin of the spermatozoa. The lack of binding to ejaculated spermatozoa was evidence that protein from the seminal plasma had already filled the available sites on the membrane. For spermatozoa from vesiculectomized boars the binding of protein was incomplete and certain areas of the head and tail were still able to adsorb colloidal particles. Intact boar spermatozoa may bind cationic proteins from the seminal plasma; these proteins would be adsorbed more strongly than the mainly anionic proteins available in the seminal plasma of boars without vesicles (Davies et al., 1975) and thus prevent the adherence of colloidal particles.

In this study experimental procedures followed to some extent those that take place during the freezing of boar semen for long-term preservation. However, instead of a casein or egg-yolk diluent, a simple diluent was used so that the components involved in cold shock could be more easily studied. Shannon \& Curson (1972) demonstrated that egg yolk protected bovine spermatozoa against the detrimental effects of seminal plasma, probably by coating the surface of the spermatozoa (Mann, 1964; Watson, 1975). Egg yolk provides some protection from cold shock to boar spermatozoa but is not as effective as with bull spermatozoa. This may be due to the basic proteins from the seminal plasma binding strongly to the plasma membrane and increasing the permeability of the membrane in a manner analogous to the effects on other biological membranes (Ryser \& Hancock, 1965; Drew \& McLaren, 1970; Hibbitt \& Benians, 1971). The effect may be enhanced by cooling and, due to the strong adherence of the basic proteins on to the membrane, egg yolk would be inadequate to counteract the effect. The use of vesiculectomized boars to provide spermatozoa that can be readily protected against cold shock is now being investigated.

We thank Mrs P. Bland for assistance and other members of the Department of Cellular Pathology for the electron photomicrographs, and the Meat and Livestock. Commission for a studentship to H.D.M.M.

\section{References}

BenNetT, J.P. \& DotT, H.M. (1967) Effect of seminal plasma on epididymal spermatozoa. Int. J. Fert. 12, 21-24.
BouRSNeLL, J.C. (1967) Boar seminal haemagglutinin. II. Combination with red cells and spermatozoa. $J$. Reprod. Fert. 13, 297-314. 
Boursnell, J.C. \& Briggs, P.A. (1969) Boar seminal plasma proteins. II. Electrophoretic identification of the haemagglutinin. $J$. Reprod. Fert. 19, 157-166.

Boursnele, J.C., Johnson, P. \& ZAMORA, J. (1962) An electrophoretic and ultracentrifuge study of boar seminal plasma. Biochim. biophys. Acta 63, 374-381.

Bower, R.E., JR, Crabo, B.G., Pace, M.M. \& Graham, E.F. (1973) Effect of dilution and glycerol on the release of glutamic oxaloacetic transaminase (GOT) from boar spermatozoa. J. Anim. Sci. 36, 319-324.

Crabo, B.G., Brown, K.I. \& Graham, E.F. (1972) Effects of some buffers on storage and freezing of boar spermatozoa. J. Anim. Sci. 35, 377-382.

Davies, C., Hall, G., Hibitt, K.G. \& Moore, H.D.M. (1975) The removal of the seminal vesicle glands from the boar and the effects on semen characteristics. J. Reprod. Fert. 43, 305-312.

Drew, M. \& McLaren, S. (1970) The effect of histones and other basic macromolecules on cell permeability and elongation of barley roots. Physiologia Pl. 23, 544-560.

Du Mesnil du Buisson, F. \& Jondet, R. (1961) Utilisation du $\mathrm{CO}_{2}$ dans l'insemination porcine. Proc. 4th Int. Congr. Anim. Reprod. \& A.I., The Hague 4, 822-827.

Fulka, J., Surcova, H. \& Valenta, M. (1965) Protein polymorphism of the seminal vesicles of bulls and the sensitivity of bull spermatozoa to cold shock. Proc. 9th Europ. Conf. Anim. Blood Groups, pp. 381-386.

Gasic, G.J., Berwick, L. \& Sorrento, M. (1968) Positive and negative colloidal iron as cell surface electron stains. Lab. Invest. 18, 63-71.

Graham, E.F. \& PACE, M.M. (1967) Some biochemical changes in spermatozoa due to freezing. Cryobiology 4, 75-85.

HaNCOCK, J.L. \& Hovell, G.L.C. (1959) The collection of boar semen. Vet. Rec. 71, 664-665.

Hibiit, K.G. \& Benians, M. (1971) Some effects in vivo of the teat canal and effects in vitro of cationic proteins on staphylococci. J. gen. Microbiol. 68, 123-128.

JoNES, R.C. (1973) Preparation of spermatozoa for electron and light microscope. J. Reprod. Fert. 33, 145-149.

Kornberg, A. (1955) Lactic dehydrogenase of muscle. Meth. Enzym. 1, 441-443.

LASLEY, J.F. \& BogarT, R. (1944) A comparative study of epididymal and ejaculated spermatozoa of the boar. J. Anim. Sci. 3, 360-370.

LASLEY, J.F. \& MAYER, D.T. (1944) A variable physiological factor necessary for the survival of bull spermatozoa. J. Anim. Sci. 3, 129-135.

LAYNE, E. (1957) Protein estimation by ultraviolet absorption. Meth. Enzym. 3, 451-454.
MANn, T. (1964) The Biochemistry of Semen and of the Male Reproductive Tract. Methuen, London.

MAtouseK, J. (1964) Antigenic characteristics of spermatozoa from bulls, rams and boars. III. Absorption analysis, precipitins and fructolysis in relation to the antigenicity of bull spermatozoa. J. Reprod. Fert. 8, 13-21.

Moellering, H. \& Gruber, W. (1966) Determination of citrate with citrate lyase. Analyt. Biochem. 17, 369-379.

MoORE, H.D.M. \& HibiIT, K.G. (1976) The binding of labelled basic proteins by boar spermatozoa. J. Reprod. Fert. 46, 71-76.

Morita, Z. \& Chang, M.C. (1970) The motility and aerobic metabolism of spermatozoa in laboratory animals with special reference to the effect of cold shock and the importance of calcium for the motility of hamster spermatozoa. Biol. Reprod. 3, 169-179.

PACE, M.M. \& GrahaM, E.F. (1970) The release of glutamic oxaloacetic transaminase from bovine spermatozoa as a test of assessing semen quality and fertility. Biol. Reprod. 3, 140-146.

Polge, C. (1956) Artificial insemination in pigs. Vet. Rec. 68, 62-78.

Pursel, V.G., Johnson, L.A. \& Gerrits, P.J. (1968) GOT and LDH enzyme activities in cold shocked and frozen boar semen. J. Anim. Sci. 27, 1788.

Pursel, V.G., Johnson, L.A. \& Rampacek, G.B. (1972) Acrosome morphology of boar spermatozoa incubated before cold shock. J. Anim. Sci. 34, 278-283.

QuinN, P.J. \& White, J.G. (1966) The effect of cold shock and deep freezing on the concentration of major cations in spermatozoa. J. Reprod. Fert. 12, 263-270.

Roberts, T.K., Boursnell, J.C. \& Brown, A.D. (1974) The role of zinc in promoting the opalescence and cold precipitation of boar seminal plasma. II. Relationships of a zinc-precipitable protein with the haemagglutinin. J. Reprod. Fert. 37, 373-386.

RySer, J.J.-P. \& HANCOCK, R. (1965) Histones and basic polyamino acids stimulate the uptake of albumin by tumor cells in culture. Science, N.Y. 150, 501-503.

Shannon, P. \& Curson, B. (1972) The effects of egg yolk levels on bovine seminal plasma and dead sperm toxins. Proc. 7 th Int. Congr. Anim. Reprod. \& A.I., Munich 2, 1316-1317.

SIZER, I.W. \& JENKINS, W.T. (1962) Glutamic aspartic transaminase from pig ventricles. Meth. Enzym. 5, 677-684.

WATSON, P.F. (1975) Interaction of egg yolk and ram spermatozoa studied with a fluorescent probe. J. Reprod. Fert. 42, 105-111.

Weil, A.J. \& FinkLeR, A.E. (1958) Antigens of rabbit semen. Proc. Soc. exp. Biol. Med. 98, 794-797.

Received 19 August 1975 